\title{
Influence of Meloidogyne javanica and Rotylenchulus reniformis alone on nodulation of some leguminous crops
}

\author{
Montasser, S.A.*; Mahmoud, N.A. ${ }^{* *}$; El-Mesalamy, A.F. ${ }^{* *}$ and Abdel-Mageed, M.A.** \\ ${ }^{*}$ Agric. Zool. and Nematol. Dept., Fac. Agric. Al-Azhar University. Cairo. \\ ** Agric. Zool. and Nematol. Dept., Fac. Agric. Al-Azhar University. Assiut Branch.
}

\begin{abstract}
The effect of root-knot nematode, Meloidogyne javanica and the reniform nematode, Rotylenchulus reniformis alone on nodulation of four Rhizobium species on roots of 27 cultivars related to six leguminous species were evaluated. The formation of nodules on their roots varied greatly in their numbers according to host species, host cultivars, rhizobal species and nematode species. The greater nodulation reduction in infected roots with nematode species, $M$. javanica and $R$. reniformis was observed on roots of common bean cvs. Exira, Nebraska, Polista and Savana inoculated with rhizobial species Rhizobium phaseoli and lupine cv. Giza 2 inoculated with rhizobial species $R$. lupine. In general, inoculation of $M$. javanica or $R$. reniformis with rhizobial species greatly reduced root nodulation as compared to leguminous species inoculated with Rhizobium species alone. Also, it is important to note that the reduction in the number of bacterial nodules was more pronounced with $R$. reniformis infection than with $M$. javanica infection. It is noteworthy that the number of nodules on roots of broad bean $\mathrm{cv}$. Wade 1 inoculated with $R$. phaseoli increased by both nematode species infections.
\end{abstract}

Key words: Rhizobium, nodulation, Meloidogyne javanica, Rotylenchulus reniformis, leguminous.

\section{Introduction}

Nodulation is an ecologically and economically important plant phenomenon, in which the symbiosis between plants from the family Fabaceae and Rhizobium results in the development of nitrogen fixing nodules on the roots of the host plant. In this organ, the bacteria differentiate into bacteroids, fix nitrogen for the plant host and in return are provided with carbon by the host plant (Crespi \& Gálvez, 2000; Hirsch et al., 2001). Root-knot nematode infection is typically associated with the formation of multinucleate cells that usually develop from vascular parenchyma cells (Davis, 1959) Histological effects induced by root-knot nematode in nodular tissues of legumes have been reported in common bean (Yousif, 1972), cowpea (Kassab, 1974), and peanut (Taha \& Yousif, 1976). The previous studies have shown that M. Javanica and M. incognita drastically inhibited nitrogen fixation (Taha et al., 1974) and nodulation of four leguminous crops: horse bean (Vicia faba), lupine (Lupinus termis), pea (Pisum sativum), and clover (Trifolium alexandrinum). Nematode galls on the roots may affect nodulation by causing nutrient deficiency in 
host plants and by occupying space on the root system. (Masefield, 1958) and (Malek \& Jenkins 1964). The formation of giant cells in vascular bundles of nodules and roots, and the basal connection of the nodule, were usually associated with abnormal xylem and/or deformed xylem strands. However, giant cells did not disturb or prevent the development of nodular tissues (Yousif, 1978). Nodule formation was hindered only when $R$. reniformis infection preceded rhizobia inoculation. (Taha \& Kassab 1980). Severe nitrogen deficiency and retarded growth than plants inoculated with nematodes only or un-inoculated plants. Nematode invasion reduced the numbers of nodules and inhibited nitrogen fixation by about $63 \%$ in nodular tissue (Ali et al., 1981). M. incognita reduced the leghaemoglobin and bacteroid content of nodules thus adversely affecting the functioning of nodules of mungbean (Vigna radiate) (Chahal \& Chahal, 1989). In the tropical climate of Venezuela, Rotylenchulus reniformis reproduced rapidly on soybean (Glycine max) roots and the nematode also, infected the Rhizobium root nodules. (Meredith et al., 1983). The root-knot nematode, M. javanica reduced nodulation on roots of broad bean (El-Bahrawy \& Salem, 1989). Lentil seedlings (Lens culinaris Medic.) suffered greater damage from $M$. incognita and $R$. reniformis individually or concomitantly, when plants were not infected with Rhizobium (Fazal et al., 1992). With the exception of common bean genotype M 28, Meloidogyne infection caused significant reductions in nodulation (Kimenju et al., 1999). Inoculation of 100 and above $R$. reniformis reduced the nodule, fresh and dry weight of shoot and root of French bean (Vadhera \& Dave, 2000). M. incognita resulted in significant decrease in the growth of black gram, root-nodule development, nitrogen contents of root and shoot, and nitrogenase activity at all inoculation levels (Bhat et al., 2012). Application of $M$. incognita or Xanthomonas campestris prior to Rhizobium sp. caused a greater reduction in chickpea plant growth than Rhizobium sp. applied prior to M. incognita or $X$. campestris (Siddiqui et al., 2013).

\section{Materials and Methods}

Seeds of six cultivars broad bean (Vicia faba L.) viz Giza 3, Giza 40, Giza 843, Maser 1, Maser 3 and Wade 1, seven common bean (Phaseolus vulgaris) cvs. Bronco, Exira, Giza 6, Nebraska, Neuten, Polista and Savana, two fenugreek (Trigon foenum-graecum) cvs. Giza 2 and Giza 3, six lentil (Lens culinaris) cvs. Giza 4, Giza 9, Giza 29, Giza 37, Giza 51 and Siena 1, three lupine (Lupinus termis) cvs. Dagon 2, Giza 1 and Giza 2 and three pea (Pisum sativum) cvs. Master Be, Victory and Lincoln obtained from the Agricultural Research Center (Giza Elmenia, Mallawe - New Valley, AlKharga). Rhizobial inoculum was obtained from Microbiology Department of Agricultural Research Center in Giza.

Seed cultivars of (broad bean \& common bean, lentil \& pea, fenugreek and lupine were mixed with rhizobial species; Rhizobium phaseoli, R. leguminosarum, $R$. meliloti and $R$. lupini respectively, and immediately planted in pots $(25 \mathrm{~cm}$ diameter). After two weeks plants were inoculated with 1000 newly hatched 
juveniles of Meloidogyne javanica or 1000 immature females of Rotylenchulus reniformis per plant by pipetting the nematode suspension in five holes around the root system. Each of the treatments was replicated four times. The various treatments were: Rhizobium alone, M. javanica inoculation two weeks after rhizobial inoculation, and $R$. reniformis inoculation two weeks after rhizobial inoculation.

Then the pots were arranged in randomized block design on a bench in a greenhouse. All plants were grown during the normal growing seasons at a greenhouse temperature $20 \pm 5 \mathrm{C}^{\circ}$. after forty five days of inoculation, plants were gently uprooted from the pots and shaken to remove adhering soil. The total number of nodules on each plant was recorded.

\section{Results and Discussion}

Data presented in Tables ( 1 \& 2) and Figs. (1 \& 2) indicate that, the formation of nodules on their roots varied greatly in their numbers according to host species, host cultivars, Rhizobium species and nematode species.

The root-knot nematode, $M$. javanica infection was found to cause significant reduction in the number of nodules on roots of broad bean cvs. Giza 40 and Giza 843 and common bean cv. Bronco inoculated with rhizobial species Rhizobium phaseoli with rates of 38.23, 29.41 and $42.85 \%$ respectively, lentil cvs. Giza 4, Giza 29 and Giza 51 inoculated with rhizobial species $R$. leguminosarum with rates of 25.00, 71.87 and $52.56 \%$ respectively, lupine cv. Degon 2 inoculated with rhizobial species $R$. lupine with rate of $44.44 \%$ and pea cvs. Lincoln, Master Be and Victory inoculated with rhizobial species $R$. leguminosarum with rates of $64.58,62.00$ and $30.90 \%$ respectively. Table (1) and Fig. (1).

Also, the reniform nematode, $R$. reniformis infection was found to cause significant reduction in the number of nodules on roots of broad bean cvs. Giza 3, Maser 1 \& Maser 3 and common bean cvs. Giza 6 and Neuten inoculated with rhizobial species Rhizobium phaseoli with rates of 49.47, 68.03, 12.06, 52.00 and $45.16 \%$ respectively, fenugreek cvs. Giza 2 and Giza 3 inoculated with rhizobial species $R$. meliloti with rates of 61.29 and $68.30 \%$ respectively, lentil cvs. Giza 9, Giza 37 and Siena 1 inoculated with rhizobial species $R$. leguminosarum with rates of $78.68,50.00$ and $64.22 \%$ respectively, lupine cv. Giza 1 inoculated with rhizobial species $R$. lupine with rate of $57.69 \%$. Table (1) and Fig. (1).

On the other hand, a similar greater nodulation reduction in infected roots with nematode species, Meloidogyne javanica and Rotylenchulus reniformis was observed on roots of common bean cvs. Exira, Nebraska, Polista and Savana inoculated with rhizobial species Rhizobium phaseoli with rates of 48.83, 54.09, 48.88 and $77.77 \%$ respectively and lupine cv. Giza 2 inoculated with rhizobial species $R$. lupine with rate of $68.29 \%$ (Tables 1 - 2 and Figs. 1 - 2). 
Table (1): Effect of Meloidogyne javanica on nodulation of four inoculated Rhizobium species for some cultivars of six leguminous species.

\begin{tabular}{|c|c|c|c|c|c|}
\hline \multirow[b]{2}{*}{ Leguminous crops } & \multirow[b]{2}{*}{ Cultivars } & \multicolumn{2}{|c|}{ No. of nodules on roots. } & \multirow[b]{2}{*}{ Decrease } & \multirow{2}{*}{$\begin{array}{c}\% \\
\text { reduction }\end{array}$} \\
\hline & & $\begin{array}{l}\text { Rhizobium + } \\
\text { Meloidogyne } \\
\end{array}$ & $\begin{array}{c}\begin{array}{c}\text { Rhizobium } \\
\text { Alone }\end{array} \\
\end{array}$ & & \\
\hline \multirow{7}{*}{$\begin{array}{l}\text { Broad bean } \\
\text { (Vicia faba L.) }\end{array}$} & \multicolumn{5}{|c|}{ Rhizobium phaseoli } \\
\hline & Giza 3 & $63 *$ & 95 & 32 & 33.68 \\
\hline & Giza 40 & 63 * & 102 & 39 & 38.23 \\
\hline & Giza 843 & 48 & 68 & 20 & 29.41 \\
\hline & Maser 1 & 51 * & 122 & 71 & 58.19 \\
\hline & Maser 3 & 55 & 58 & 3 & 5.17 \\
\hline & Wade 1 & 51 & 46 & - & - \\
\hline \multirow{8}{*}{$\begin{array}{c}\text { Common bean } \\
\text { (Phaseolus vulgaris) }\end{array}$} & \multicolumn{5}{|c|}{ Rhizobium phaseoli } \\
\hline & Bronco & 16 & 28 & 12 & 42.85 \\
\hline & Exira & 22 ** & 43 & 21 & 48.83 \\
\hline & Giza 6 & $14^{*}$ & 25 & 11 & 44.00 \\
\hline & Nebraska & 28 * & 61 & 33 & 54.09 \\
\hline & Neuten & 23 * & 31 & 8 & 25.80 \\
\hline & Polista & 23 * & 45 & 22 & 48.88 \\
\hline & Savana & 20 ** & 90 & 70 & 77.77 \\
\hline \multirow{3}{*}{$\begin{array}{l}\text { Fenugreek } \\
\text { (Trigon foenum- } \\
\text { graecum) }\end{array}$} & \multicolumn{5}{|c|}{ Rhizobium meliloti } \\
\hline & Giza 2 & $75^{*}$ & 155 & 80 & 51.61 \\
\hline & Giza 3 & $55^{* *}$ & 142 & 87 & 61.26 \\
\hline \multirow{7}{*}{$\begin{array}{c}\text { Lentil } \\
\text { (Lens culinaris) }\end{array}$} & \multicolumn{5}{|c|}{ Rhizobium leguminosarum } \\
\hline & Giza 4 & $21 *$ & 28 & 7 & 25.00 \\
\hline & Giza 9 & 78 * & 122 & 44 & 36.06 \\
\hline & Giza 29 & $9^{* *}$ & 32 & 23 & 71.87 \\
\hline & Giza 37 & $25^{* *}$ & 44 & 19 & 43.18 \\
\hline & Giza 51 & $37^{* *}$ & 78 & 41 & 52.56 \\
\hline & Siena 1 & $41^{* *}$ & 109 & 68 & 62.38 \\
\hline \multirow{4}{*}{$\begin{array}{c}\text { Lupine } \\
\text { (Lupinus termis) }\end{array}$} & \multicolumn{5}{|c|}{ Rhizobium Iupini } \\
\hline & Degon 2 & $15^{*}$ & 27 & 12 & 44.44 \\
\hline & Giza 1 & $17^{*}$ & 26 & 9 & 34.61 \\
\hline & Giza 2 & 13 * & 41 & 28 & 68.29 \\
\hline \multirow{4}{*}{$\begin{array}{c}\text { Pea } \\
\text { (Pisum sativum) }\end{array}$} & \multicolumn{5}{|c|}{ Rhizobium leguminosarum } \\
\hline & Lincoln & $17^{* *}$ & 48 & 31 & 64.58 \\
\hline & Master be & $19^{* *}$ & 50 & 31 & 62.00 \\
\hline & Victory & 38 * & 55 & 17 & 30.90 \\
\hline
\end{tabular}

*Significant at 0.05 level of probability by student t-test. **Highly Significant at 0.01 level of probability. 


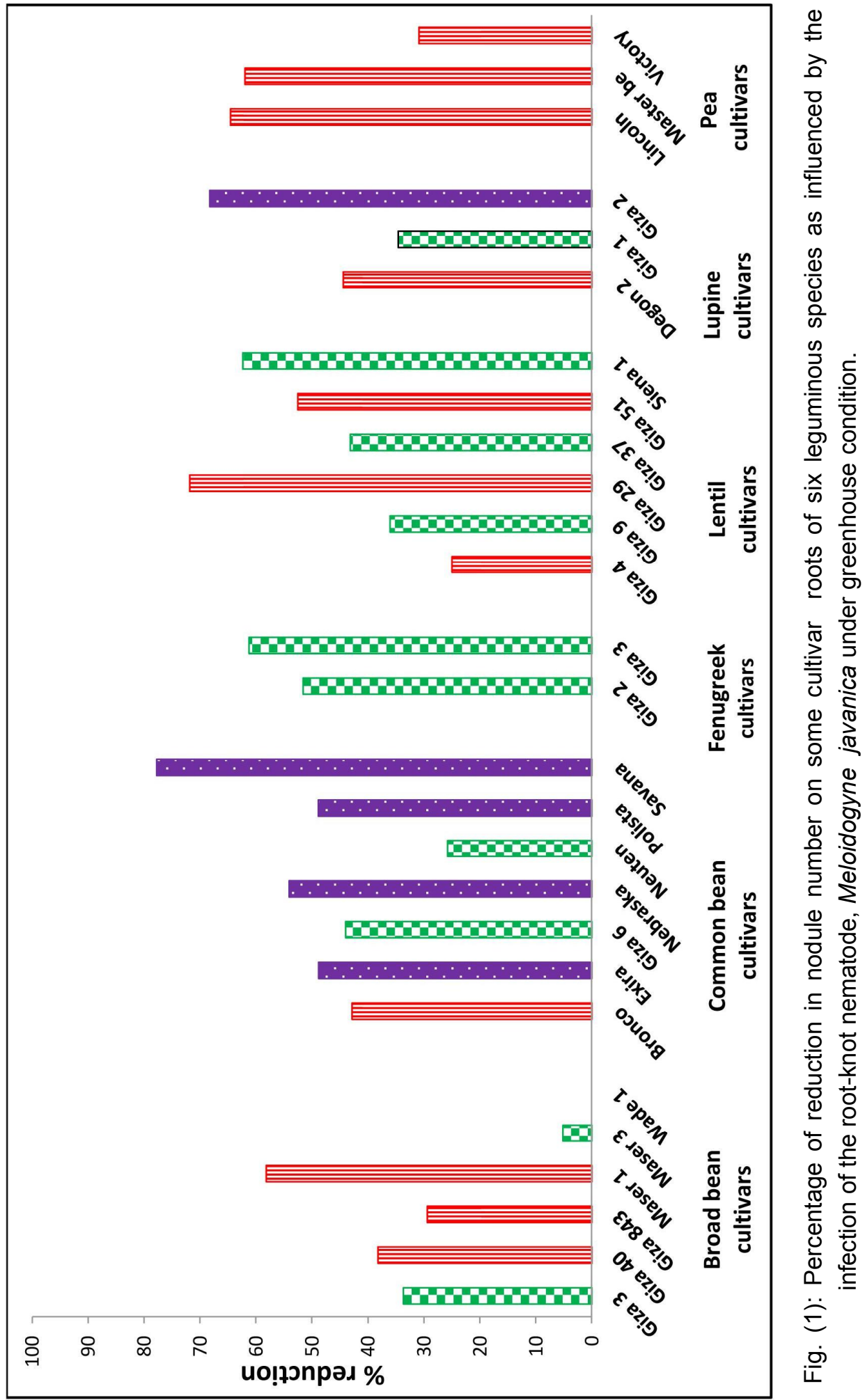

Egypt. J. Agronematol., Vol. 15, No. 1, (2016) 
Table (2): Effect of Rotylenchulus reniformis on nodulation of four inoculated Rhizobium species for some cultivars of six leguminous species.

\begin{tabular}{|c|c|c|c|c|c|}
\hline \multirow{2}{*}{ Leguminous crops } & \multirow{2}{*}{ Cultivars } & \multicolumn{2}{|c|}{ No. of nodules on roots. } & \multirow{2}{*}{ Decrease } & \multirow{2}{*}{$\begin{array}{c}\% \\
\text { Reduction }\end{array}$} \\
\hline & & $\begin{array}{c}\text { Rhizobium + } \\
\text { Rotylenchulus }\end{array}$ & $\begin{array}{c}\begin{array}{c}\text { Rhizobium } \\
\text { alone }\end{array} \\
\end{array}$ & & \\
\hline \multirow{7}{*}{$\begin{array}{l}\text { Broad bean } \\
\text { (Vicia faba L.) }\end{array}$} & \multicolumn{5}{|c|}{ Rhizobium phaseoli } \\
\hline & Giza 3 & 48 * & 95 & 47 & 49.47 \\
\hline & Giza 40 & 90 & 102 & 12 & 11.76 \\
\hline & Giza 843 & 49 * & 68 & 19 & 27.94 \\
\hline & Maser 1 & 39 ** & 122 & 83 & 68.03 \\
\hline & Maser 3 & 51 & 58 & 7 & 12.06 \\
\hline & Wade 1 & 61 & 46 & - & - \\
\hline \multirow{8}{*}{$\begin{array}{c}\text { Common bean } \\
\text { (Phaseolus vulgaris) }\end{array}$} & \multicolumn{5}{|c|}{ Rhizobium phaseoli } \\
\hline & Bronco & $17^{*}$ & 28 & 11 & 39.28 \\
\hline & Exira & 22 ** & 43 & 21 & 48.83 \\
\hline & Giza 6 & 12 & 25 & 13 & 52.00 \\
\hline & Nebraska & 28 * & 61 & 33 & 54.09 \\
\hline & Neuten & 17 & 31 & 14 & 45.16 \\
\hline & Polista & 23 * & 45 & 22 & 48.88 \\
\hline & Savana & 20 ** & 90 & 70 & 77.77 \\
\hline \multirow{3}{*}{$\begin{array}{c}\text { Fenugreek } \\
\text { (Trigon foenum- } \\
\text { graecum) }\end{array}$} & \multicolumn{5}{|c|}{ Rhizobium meliloti } \\
\hline & Giza 2 & $60 *$ & 155 & 95 & 61.29 \\
\hline & Giza 3 & $45^{*}$ & 142 & 97 & 68.30 \\
\hline \multirow{7}{*}{$\begin{array}{c}\text { Lentil } \\
\text { (Lens culinaris) }\end{array}$} & \multicolumn{5}{|c|}{ Rhizobium leguminosarum } \\
\hline & Giza 4 & 23 & 28 & 5 & 17.85 \\
\hline & Giza 9 & 26 ** & 122 & 96 & 78.68 \\
\hline & Giza 29 & $14^{*}$ & 32 & 18 & 56.25 \\
\hline & Giza 37 & 22 & 44 & 22 & 50.00 \\
\hline & Giza 51 & 51 * & 78 & 27 & 34.61 \\
\hline & Siena 1 & 39 ** & 109 & 70 & 64.22 \\
\hline \multirow{4}{*}{$\begin{array}{c}\text { Lupine } \\
\text { (Lupinus termis) }\end{array}$} & \multicolumn{5}{|c|}{ Rhizobium lupini } \\
\hline & Degon 2 & 20 & 27 & 7 & 25.92 \\
\hline & Giza 1 & 11 * & 26 & 15 & 57.69 \\
\hline & Giza 2 & 13 * & 41 & 28 & 68.29 \\
\hline \multirow{4}{*}{$\begin{array}{c}\text { Pea } \\
\text { (Pisum sativum) }\end{array}$} & \multicolumn{5}{|c|}{ Rhizobium leguminosarum } \\
\hline & Lincoln & $18^{* *}$ & 48 & 30 & 62.50 \\
\hline & Master be & 22 * & 50 & 28 & 56.00 \\
\hline & Victory & 43 * & 55 & 12 & 21.81 \\
\hline
\end{tabular}

*Significant at 0.05 level of probability by student t-test. $\quad$ **Highly significant at 0.01 level of probability. 


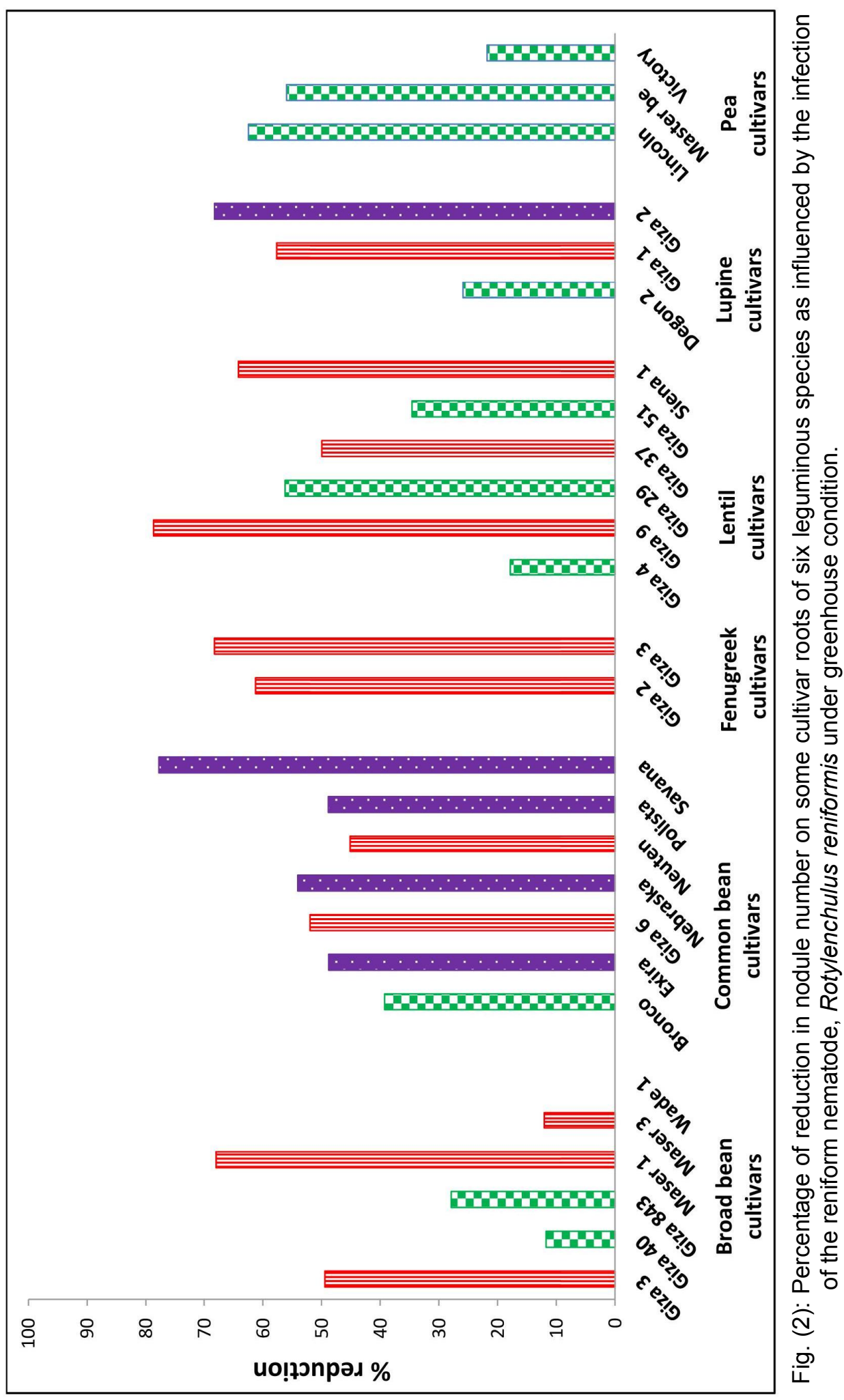

Egypt. J. Agronematol., Vol. 15, No. 1, (2016) 
In general, inoculation of $M$. javanica or $R$. reniformis with rhizobial species greatly reduced root nodulation as compared to leguminous species inoculated with Rhizobium species alone. Also, it is important to note that the reduction in the number of bacterial nodules was more pronounced with $R$. reniformis infection than with $M$. javanica infection. It is noteworthy that the number of nodules on roots of broad bean cv. Wade 1 inoculated with Rhizobium phaseoli increased by both nematode specie infections.

These findings are in agreement with reports of several investigators who found that the root-knot nematode and reniform nematodes caused reduction in nodulation on roots of some leguminous crops (Ayala, 1962; Raut and Sethi, 1980 and Verdejo et al., 1988). Several plant parasitic nematode have been found to cause great reduction in root nodulation of some leguminous crops (Romaniko, 1961; Wardojo et al., 1963 and Karanja, 1988). Also, Taha \& Raski, (1969); Hussey \& Barker, (1976); Singh \& Reddy (1981) and Siddiqui \& Mahmood (1994) showed that, early destruction of nodules as a result of nematode infection deprived the plants of some nitrogenous materials. Reduction in nodulation might be due to the formation of Meloidogyne galls thus occupying space in the roots (Malek \& Jenkins, 1964; Barker \& Hussey, 1976 and Hyens \& O’Connl, 1990) and due to suppression of lateral root formation by $R$. reniformis which might cause reduction in numbers of sites for nodule initials (Taha \& Kassab, 1980; Chahal et al., 1988 and Mohanti et al., 2001).

\section{References}

Ali, M.A.; Trabulsi, I.Y. and Abd-Elsamea, M.E. (1981). Antagonistic interaction between Meloidogyne incognita and Rhizobium leguminosarum on Cowpea. Plant Dis., 65: 432 - 435.

Ayala, A. (1962). Occurrence of the nematode Meloidogyne javanica on pigeon pea roots in Puerto Rico. J. Agric. Univ. Puerto Rico 46: 154 -156.

Barker, K.R., and Hussey, R.S. (1976). Histopathology of nodular tissues of legumes infected with certain nematodes. Phytopathol., 66: 851 - 855.

Bhat, M.Y.; Wani, A.H. and Fazal, M. (2012). Effect of Paecilomyces lilacinus and plant growth promoting rhizobacteria on Meloidogyne incognita inoculated black gram, Vigna mungo plants. J. Biopest., 5: 36 - 43.

Chahal, P.P.K. and Chahal, V.P.S. (1989). Effect of Meloidogyne incognita on leghaemoglobin, bacteroids and nitrogenase activity of nodules produced by Rhizobium spp. on mungbean (Vigna radiate L.). Pak. J. Nematol., 7: 2125.

Chahal, V.P.S.; Chahal, P.P.K. and Kapoor, S. (1988). Effect of Meloidogyne incognita on symbiosis between Rhizobium and mash (Vigna mungo). Crop Improvement, 15: 95 - 97. 
Crespi, M. and Galvez, S. (2000). Molecular mechanisms in root nodule development. J. Plant Growth Regulation 19: 155 -166.

El-Bahrawy, S.A. and Salem, F.M. (1989). Interaction between Rhizobium leguminosarum and Meloidogyne javanica nematode in broad bean under nematicide application. Zentrlblat fur Mikrobiologie 144: 279 - 281.

Fazal, M.; Siddiqui, Z.A. and Imran, M. (1992). Effect of pre-post- and simultaneous inoculations of Rhizobium, Rotylenchulus reniformis and Meloidogyne incognita on Lentil. Nematol. Medit., 20:159 - 161.

Hirsch, A.M.; Lum, M.R. and Downie J.A. (2001). What makes the RhizobiaLegume symbiosis special? Plant Phyisol. 127: 1484 - 1492.

Hussey, R. S. and Barker, K.R. (1976). Influence of nematodes and light sources on growth and nodulation of soybean. J. Nematol., 8: 48 - 52.

Hyens, M.F. and O'ConnI, M. P. (1990). Host plant effect on competition among strains of Rhizobium leguminosarum. Can. J. Microbio., 36: $864-869$.

Karanja, N.K. (1988). Selecting Rhizobium phaseoli strains for use with beans (Phaseolus vulgaris L.) in Kenya. Ph. D. Thesis, Univ. of Reading, UK. 221 pp.

Kassab, A.Sh.M. (1974). Interrelationships between root-knot nematode, reniform nematode and their leguminous host. M.Sc. thesis. Fac. Agr., Ain Shams Univ., 66 pp.

Kimenju, J.W.; Karanja, N.K. and Macharia, I. (1999). Plant parasitic nematodes associated with common bean in Kenya and the effect of Meloidogyne infection on bean nodulation. African Crop Sci. J., 7: 503 - 510.

Malek, R.B. and Jenkins, W.R. (1964). Aspects of the host-parasite relationships of nematodes and hairy vetch. Bull. N. J. Agr. Exp. Sta Bull., 8133: 31pp.

Masefield, G.B. (1958). Some factors affecting nodulation in the tropics. pp 202215 In E.G. Hallasworth (Ed.) Nutrition of the legumes. Academic Press. New York.

Meredith, J.A.; Inserra, R.N. and Fernandez, M.D. (1983). Parasitism of Rotylenchulus reniformis on soybean root Rhizobium nodules in Venezuela. J. Nematol., 15: 211-214.

Mohanti, K.C.; Dash, L. and Swain, S.C. (2001). Effect of Meloidogyne incognita on nodulation and root biochemistry in French bean. Ann of plant Protection Sci., 9: 81 - 86.

Raut, S.P. and Sethi, C.L. (1980). Effect of initial levels of Meloidogyne incognita on plant growth and rhizobial nodulation of mungbean. Indian Phytopath., 33: 351 - 352. 
Romaniko, V.I. (1961). Injury and economic damage to legumes caused by Pratylenchus globulicolan sp.. Questions Phytohelminthol., P 161-174.

Siddiqui, Z.A. and Mahmood, I. (1994). Interraction of Meloidogyne javanica, Rotylenchulus reniformis, Fusarium oxysporum, ciceri $\mathrm{sp}$. and Bradyrhizobium japonicum on the wilt disease complex of chickpea. Nematol. Medit., 22: 135 - 140.

Siddqui, Z.A.; Fatma, M. and Alam, S. (2013). Interactions of Meloidogyne incognita, Xanthomonas campestris, and Rhizobium sp. in the disease complex of chickpea. Turk. J. Agric. For, 37: 173 - 178.

Singh ,D.B. and Reddy, P.P. (1981). Influence of Meloidogyne incognita infestation on Rhizobium nodule formation in French bean. Nematol. Medit., 9: $1-5$.

Taha, A.H.Y. and Kassab, A.S. (1980). Interrelations between Meloidogyne javanica, Rotylenchulus reniformis, and Rhizobium Sp. on Vigna sinensis. J. Nematology, 12: 57 - 62.

Taha, A.H.Y. and Raski, D.J. (1969). Interrelationship between root nodules, bacteria, Plant parasitic nematode and leguminous host. J. Nematol. I: 201 - 211.

Taha, A.H.Y. and Yousif, G.M. (1976). Histology of peanut under groumt parts infected with Meloidogyne incognita. Nematol. Medit. 4:175 - 181.

Taha, A.H.Y.; Youssif, G.M. and El-Hadidy, T.T. (1974). Interaction of root-knot nematode infection and symbiotic nitrogen fixation in leguminous hosts. Ann. Agr. Sci. Fac. Agr., Ain shams Unvir. 10: 33 - 38.

Vadhera, I. and Dave, G.S. (2000). Effect of different levels of inocula of Rotylenchulus reniformis on nodulation and protein content of Frenchbean. Indian phytopath., 53: 266 - 268.

Verdejo, M.S.; Green, C.D. and Podder, A.K. (1988). Influence of Meloidogyne incognita on nodulation and growth of pea and black bean. Nematologica 34: 88 - 97.

Wardojo, S.; Hijink, M.J. and O'ostenbrink, M. (1963). Damage to white clover by inoculation of Heterodera trifollii, Meloidogyne hapla and Pratylenchus penetrans. $\mathrm{XV}^{\text {th }}$ Int. Symp. Crop Protection. P. 101.

Yousif, G.M. (1972). Studies on the problem of nematodes in sandy soil with special reference to its non-chemical control method. Ph. D. Thesis, Fac. Agric., Ain Shams Univ., 80 pp.

Youssif, G.M. (1978). Histological responses of four leguminous crops infected with Meloidogyne incognita. J. Nematol., 11: 359 - 401. 


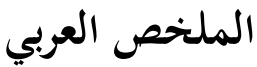

تأثير نيماتودا تعقد الجذور والنيماتودا الكلوية على تكوين العقد البكتيرية في بعض المحاصيل البقولية

\footnotetext{
سيد عبد العزيز منتصرّ*، نشأت عبد العزيز محمود***، أنس فرج محمد المسلمي **، محمد عبد المجيد * قسم الحيوان الزراعي والنيماتودا - كلية الزراعة - جامعة الأزهر - القاهرة. **قم الحيوان الزراعي والنيماتودا - كلية الزراعة - جامعة الأزهر - فرع أسيوط.
}

تلعب بكتريا العقد الجذرية Rhizobium دورًا حيويًا في الزراعة حيث تكون العقد

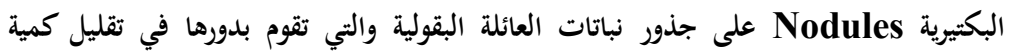
الأسمدة الكيماوية النيتروجينية المضافة للتربة خلال فترة نمو هذه المبالية المحاصيل.

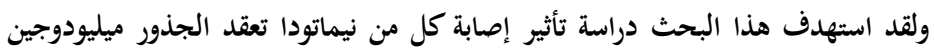

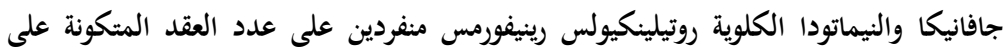

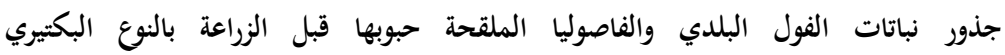
Rhizobium meliloti والحلبة بالنوع البكتيري العداء والبسلة بالنوع البكتيري Rhizobium leguminosarum والثرمس بالنوع البكتيري

\section{Rhizobium lupini}

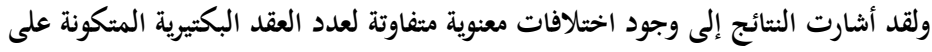

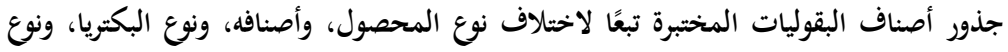

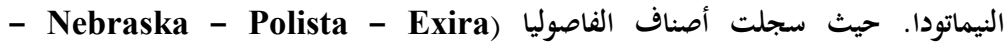
(Savana

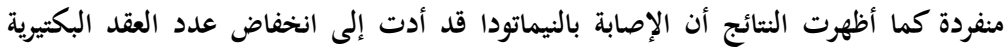

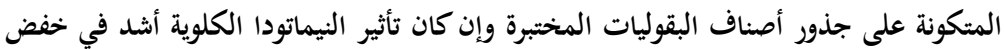

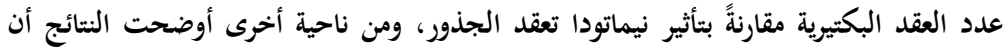

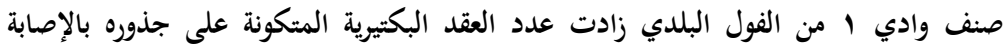
بالنيماتودا الكلوية أو نيماتودا تعقد الجذور. 